\title{
Possible regulatory role of Snail in NF-кB-mediated changes in E-cadherin in gastric cancer
}

\author{
ZENAN HU ${ }^{1,2}$, XIAOJUN LIU $^{1}$, ZHIFENG TANG ${ }^{1}$, YONGNING ZHOU ${ }^{1,2}$ and LIANG QIAO ${ }^{3}$ \\ ${ }^{1}$ First Clinical Medical School of Lanzhou University, Lanzhou 730000; ${ }^{2}$ Department of Gastroenterology and Hepatology, \\ The First Hospital of Lanzhou University, Lanzhou 730000, P.R. China; ${ }^{3}$ Storr Liver Unit, Westmead Millennium Institute \\ and Western Clinical School, Department of Medicine, The University of Sydney, Westmead NSW 2145, Australia
}

Received September 17, 2012; Accepted October 30, 2012

DOI: $10.3892 /$ or.2012.2200

\begin{abstract}
In the present study, we aimed to investigate the involvement of Snail in NF- $\mathrm{BB}$-mediated changes of E-cadherin in gastric cancer. A total of 189 human gastric cancer tissues, and 32 normal gastric mucosal tissues were used to determine the expression levels of NF- $\mathrm{KB}, \mathrm{E}$-cadherin and Snail by immunohistochemistry. The correlation between the expression levels and patient clinicopathological data was analyzed. Human gastric cancer cell line SGC7901 was treated with the NF- $\mathrm{KB}$ inhibitor PDTC, and the expression levels of E-cadherin and Snail were investigated by qPCR and western blot. NF-kB, E-cadherin and Snail were all detected in normal gastric mucosa and cancer tissues of various differentiation statuses. However, the expression patterns of each protein were different. Strong expression of E-cadherin was detected in normal gastric mucosa, whereas its expression gradually declined in gastric cancer tissues, with weak expression observed in poorly differentiated gastric cancer tissues. In contrast, weak NF- $\kappa \mathrm{B}$ and Snail expressions were present in normal gastric mucosa, while their expression levels gradually increased in gastric cancer tissues, with the strongest expression detected in poorly differentiated gastric cancers. The expression of E-cadherin was inversely correlated with that

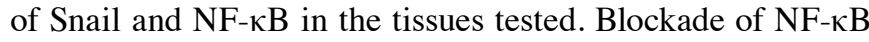
using its inhibitor PDTC led to a time-dependent reduction in
\end{abstract}

Correspondence to: Dr Liang Qiao, Storr Liver Unit, Westmead Millennium Institute, The University of Sydney at Westmead Hospital, Westmead NSW 2145, Australia

E-mail: liang.qiao@sydney.edu.au

Professor Yongning Zhou, Department of Gastroenterology and Hepatology, The First Hospital of Lanzhou University, No. 1 West Donggang Road, Lanzhou 730000, P.R. China

E-mail: yongningzhou@sina.com

Abbreviations: $\mathrm{NF}-\kappa \mathrm{B}$, nuclear factor- $\kappa \mathrm{B}$; PDTC, pyrrolidine dithiocarbamate

Key words: E-cadherin, Snail, NF-кB, gastric cancer
Snail but a time-dependent increase in E-cadherin in SGC7901 cells. These results suggest that in human gastric cancer, loss of E-cadherin may be mediated through NF- $\kappa B$-induced Snail upregulation. Further studies may reveal whether targeting the NF-kB-Snail-E-cadherin axis could be a useful approach for combating gastric cancer.

\section{Introduction}

Gastric cancer is a major public health issue worldwide particularly in China. According to cancer statistics published in 2011, gastric cancer is the fourth most frequently diagnosed cancer and the third most common cause of cancer-related mortality in men, whereas in women it is the fifth most common malignancy in regards to incidence and mortality rate $(1,2)$. The highest incidence rates of gastric cancer are in Eastern Asia, Eastern Europe and South America (1,2). In China, gastric cancer is the third most common malignancy and the leading cause of cancer-related death $(3,4)$. Lack of effective treatment options for advanced gastric cancer is largely due to a poor understanding of the molecular mechanisms involved in the development of gastric cancer.

Nuclear factor- $\kappa \mathrm{B}(\mathrm{NF}-\kappa \mathrm{B})$ is a ubiquitously expressed family of Rel-related transcription factors (5). Abnormal activation of NF- $\mathrm{BB}$ reduces cell sensitivity to apoptotic stimuli and therefore facilitates the survival of transformed cells (6). NF- $\kappa \mathrm{B}$ is involved in the control of cell growth and oncogenesis. Constitutive activation of NF- $\mathrm{kB}$ in cancer cells is partially responsible for the observed resistance to chemotherapy and radiotherapy (7). As a ubiquitous transcription factor, NF- $\mathrm{kB}$ regulates the expression and function of numerous target genes, among which and of most relevance to cancer development is E-cadherin.

E-cadherin is a major cell-cell adhesion molecule that plays a significant role in the establishment and maintenance of cell-cell interactions and tissue architecture (8-10). A negative correlation between NF- $\kappa \mathrm{B}$ and E-cadherin in gastric cancer cells has recently been reported (11). It was recently shown that connective tissue growth factor (CTGF) downregulated the expression of E-cadherin through activation of NF- $\kappa B$ (11). Loss of E-cadherin expression is associated with enhanced tumor progression, increased invasive and metastatic potential of cancer cells and a poor overall prognosis in 
patients with gastric cancer and other malignancies (12-15). However, as gastric cancer is a multifactorial disease (16), loss of E-cadherin alone cannot explain the increased malignant tendency of gastric cancer cells (17). Interaction between E-cadherin and other genes could well be involved in the development of gastric cancer and its malignant phenotype.

We supposed that Snail may be a critical factor in mediating the regulatory role of NF- $\mathrm{KB}$ on its target genes, which has not been reported in the literature. Snail is a member of the Snail superfamily of zinc finger transcription factors (18). It plays an important role in embryonic development, neural differentiation, cell division and survival $(19,20)$. Overexpression of Snail mRNA was able to downregulate the expression of E-cadherin in diffuse-type gastric carcinoma $(21,22)$. However, it is not clear whether Snail is a critical transcription factor for the regulatory role of NF- $\mathrm{kB}$ regarding its target genes.

This study aimed to evaluate whether NF- $\mathrm{KB}$-mediated changes in E-cadherin are regulated through Snail.

\section{Materials and methods}

Donor blocks and patient information. Paraffin-embedded blocks of gastric tissues (previously fixed in $10 \%$ formaldehyde) were obtained from 189 patients with gastric cancer who underwent surgical operations at the Wuwei Tumor Hospital, Gansu Province, China. The diagnosis of gastric adenocarcinoma was based on the World Health Organization (WHO) diagnostic criteria, and was confirmed by two independent pathologists. Based on the WHO Classification of Tumors of the Digestive System (23), there were 100 cases of poorly differentiated gastric adenocarcinoma, 44 cases of moderately differentiated gastric adenocarcinoma, and 45 cases of well-differentiated gastric adenocarcinoma. The patient study population had a mean age of 55 (range, 30-73) years at the time of operation, with an overall male to female ratio of 3.3:1. None of the patients had received any chemotherapy and/or radiotherapy prior to surgery. The detailed patient characteristics are summarized in Table I. Paraffin-embedded blocks of normal gastric mucosal tissues $(n=32)$ were obtained from healthy subjects who underwent gastroscopy in the same hospital for other non-malignant gastric conditions. Written consent from all patients was obtained prior to the study. The study was approved by the Institutional Human Ethics Committee of the First Clinical School of Lanzhou University.

Tissue microarray (TMA) construction. The collected paraffin blocks were used as donor blocks to make eight TMA recipient blocks. In each donor block, morphologically representative areas were chosen and marked on their respective $H \& E$ slides. A tissue core of $0.6 \mathrm{~mm}$ in diameter from each donor block was taken using a cylindrical tissue puncher (Beecher, Beecher Instruments, Silver Spring, MD, USA) and transferred into the hole on the recipient paraffin block. The distance between each recipient hole was kept constant at $1 \mathrm{~mm}$. Duplicate tissue cores from each donor tissue were positioned side by side. The detailed matrix plan for the arrangement of the constructed TMA was recorded for correct tissue identification.

Immunohistochemistry assays. The above-constructed TMA blocks were cut into sections of $4-\mu \mathrm{m}$ thickness, dewaxed
Table I. Clinicopathological features of the 189 patients with gastric cancer.

\begin{tabular}{lcc}
\hline Characteristics & No. of cases & $\%$ \\
\hline Gender & & \\
Female & 44 & 23.3 \\
Male & 145 & 76.7 \\
Age (years) & & \\
$<50$ & 51 & 27 \\
$\geq 50$ & 138 & 73 \\
Tumor size (cm) & & \\
$<5$ & 70 & 37 \\
$\geq 5$ & 119 & 63 \\
Lymph node metastasis & & \\
No & 73 & 38.6 \\
Yes & 116 & 61.4 \\
Tumor differentiation status & & \\
Well/moderate & 89 & 47.1 \\
Poor & 100 & 52.9 \\
Depth of tumor invasion & & \\
Without serosal invasion & 46 & 24.3 \\
Serosal invasion & 143 & 75.7 \\
Lauren classification & & \\
Intestinal type & 97 & 51.3 \\
Diffuse type & 85 & 48.7 \\
\hline
\end{tabular}

in xylene and rehydrated in graded alcohols. The slides were boiled for $30 \mathrm{~min}$ in citrate buffer $(10 \mathrm{mM}$; pH 6.0) in a microwave oven at $250-300 \mathrm{~W}$ and then cooled to room temperature. Before immunohistochemical staining, the slides were incubated with $3 \% \mathrm{H}_{2} \mathrm{O}_{2}$ in PBS for 10 min to quench the endogenous peroxidase activity, followed by incubation with 3\% BSA for 15 min to block the non-specific binding of the antibody.

For immunohistochemical staining, the slides were incubated for $1 \mathrm{~h}$ at $37^{\circ} \mathrm{C}$ with primary antibody against E-cadherin (monoclonal, dilution 1:250, Abcam, USA), NF-kB p65 (monoclonal, dilution 1:200, Abcam), and Snail (polyclonal, dilution 1:200, Abcam). The slides were then washed with PBS for three times, incubated with biotinconjugated secondary antibody (1:150, Abcam) for $40 \mathrm{~min}$ at $37^{\circ} \mathrm{C}$, washed with PBS, and then incubated with streptavidinhorseradish peroxidase (SHRP) (Thermo Fisher Scientific, USA) for $40 \mathrm{~min}$ at room temperature. DAB (2,3-diaminobenzidine tetrahydrochloride) (Beijing Zhongshan Golden Bridge Biotechnology Co., Ltd., China) was used to develop the peroxidase reaction, and the slides were counterstained with hematoxylin. The experimental validity was confirmed by using negative controls in which the primary antibody was replaced by $5 \%$ BSA. The slides were reviewed independently by two pathologists, and the staining for each protein was scored according to the criteria established in Table II and as previously reported (24). Representative areas were photographed for data presentation. 
Table II. Scoring criteria for immunohistochemistry.

\begin{tabular}{lc}
\hline Criteria & Score \\
\hline Staining positivity & \\
Positive in $<5 \%$ of the cells & 0 \\
Positive in 5-25\% of the cells & 1 \\
Positive in 26-50\% of the cells & 2 \\
Positive in >50\% of the cells & 3 \\
Staining intensity & \\
Negative (no staining) & 0 \\
Weak (light yellow) & 1 \\
Moderate (brown) & 2 \\
High (dark brown) & 3 \\
Sum of positivity and intensity scores & \\
Negative & $0-2$ \\
Weak positive & $3-4$ \\
Strong positive & $5-6$ \\
\hline
\end{tabular}

Culture of gastric cancer cells and treatment with NF- $\kappa B$ inhibitor PDTC. SGC7901 cells (a human gastric cancer cell line; Shanghai Institutes for Biological Sciences, Chinese Academy of Sciences, Shanghai, China) were cultured in RPMI-1640 medium (Gibco, Carlsbad, CA, USA) supplemented with $1 \%$ penicillin and streptomycin (Gibco) and 10\% heat-inactivated fetal bovine serum (Hangzhou Sijiqing Biological Engineering Materials Co., Ltd., Hangzhou, China) at $37^{\circ} \mathrm{C}$ in a humidified atmosphere containing 5\% carbon dioxide.

To block the activity of NF- $\kappa \mathrm{B}$, cells were treated with $50 \mu \mathrm{M}$ of a chemical inhibitor of NF- $\kappa \mathrm{B}$, pyrrolidine dithiocarbamate (PDTC). This optimal dose was based on our preliminary study by sulforhodamine B (SRB) assay, which revealed that $50 \mu \mathrm{M}$ of PDTC was able to effectively block the expression and activity of the $\mathrm{NF}-\kappa \mathrm{B}$ subunit $\mathrm{p} 65$ in gastric cancer cells. The SRB assay was performed as previously reported $(25,26)$.

Quantitative real-time PCR ( $q P C R)$. Total RNA of the treated cells was extracted using the Ze Spin Column of the Total RNA Isolation kit (Takara, Dalian, China). Total RNA (1 $\mu \mathrm{g})$ was reverse-transcribed into cDNA using the PrimeScript ${ }^{\mathrm{TM}}$ RT Reagent kit (Takara) according to the manufacturer's instructions. The synthesized cDNA samples were subjected to qPCR using SYBR ${ }^{\circledR}$ Premix Ex Taq ${ }^{\mathrm{TM}}$ reagent (Takara). All qPCR reactions were performed using Rotor-Gene 3000 (Corbett, Australia), with each PCR cycle consisting of denaturation for $15 \mathrm{sec}$ at $95^{\circ} \mathrm{C}$, annealing for $45 \mathrm{sec}$ at $62^{\circ} \mathrm{C}$ and extension for $30 \mathrm{sec}$ at $72^{\circ} \mathrm{C}$. $\beta$-actin was used as the internal reference. The qPCR primers were as follows: E-cadherin (sense: 5'-TTAAACTCCTGGCCTCAAGCAATC-3', antisense: 5'-TCCTATCTTGGGCAAAGCAACTG-3'), NF-кB/ P65 (sense: 5'-TCAGTCAGCGCATCCAGACC-3', antisense: 5'-CAGAGCCGCACAGCATTCA-3'), Snail (sense: 5'-CGC GCTCTTTCCTCGTCAG-3', antisense: 5'-TCCCAGATGA GCATTGGCAG-3'), $\beta$-actin (sense: 5'-TGGCACCCAGCA CAATGAA-3', antisense: 5'-CTAAGTCATAGTCCGCCTAG
AAGCA-3'). For data analysis, fold induction relative to internal controls was calculated by the $\Delta \mathrm{Ct}$ evaluation method.

Western blot assay. Total protein from the treated cells was extracted using RIPA buffer (Beyotime, Shanghai, China) supplemented with phenylmethylsulfonyl fluoride (PMSF) and protease inhibitor cocktails (Roche, Germany), and the protein concentrations were measured by a BCA protein quantitative assay kit (Applygen, Beijing, China). The cell lysates were cleared by centrifugation at $10,000 \times \mathrm{g}$ for $5 \mathrm{~min}$ at $4^{\circ} \mathrm{C}$. Equal amounts of total proteins were resolved on $10 \%$ polyacrylamide gels (SDS-PAGE) and transferred to PVDF membranes, which were incubated with primary antibodies (E-cadherin, $\mathrm{NF}-\kappa \mathrm{B}$ and Snail) at a dilution of $1: 1,000$ overnight at $4{ }^{\circ} \mathrm{C}$. The membranes were then incubated with HRP-conjugated secondary antibody $(1: 10,000)$ for $1 \mathrm{~h}$ at room temperature and exposed using an enhanced chemiluminescence (ECL) detection system (Applygen) and visualized by autoradiography. $\beta$-actin was used as the internal reference.

Statistical analysis. SPSS 15.0 was used for data analysis. All values are expressed as means \pm SD. The Student's t-test was used to evaluate the difference between mean values. Immunohistochemical staining was quantitated and differences between groups were assessed by the $\chi^{2}$ test. A P-value of $<0.05$ was considered to indicate a statistically significant result.

\section{Results}

Expression pattern of E-cadherin. E-cadherin was detected in all tissues tested, including normal gastric epithelial tissues, adjacent non-cancerous gastric epithelial tissues and gastric cancer tissues. In normal gastric mucosa, strong expression of E-cadherin was present as a membranous protein, with some weak staining in the cytoplasmic compartment. In gastric cancer tissues, E-cadherin was largely expressed in cytoplasmic compartments with weak expression on the membrane. Normal gastric mucosal tissues expressed a higher level of E-cadherin (Fig. 1A) than gastric cancer tissues (Fig. 1B-D). Among the gastric cancer tissues, a higher level of E-cadherin was detected in the well/moderately differentiated cancer tissues (Fig. 1B and C) than in poorly differentiated cancer tissues (Fig. 1D). Overall, E-cadherin was detected in $22 \%(41 / 189)$ of gastric cancer tissues, $55.6 \%(30 / 54)$ of matched non-cancerous gastric tissues, and $100 \%(32 / 32)$ of normal gastric mucosa. By Chi-square $\left(\chi^{2}\right)$ test, gastric cancer tissues expressed a reduced level of E-cadherin compared to the matched non-cancerous gastric tissues $\left(\chi^{2}=22.382\right.$, $\mathrm{P}=0.000)$, and normal gastric mucosa $\left(\chi^{2}=74.33, \mathrm{P}=0.000\right)$. Of note, reduced expression of E-cadherin was observed in matched non-cancerous gastric tissues when compared with tha normal gastric mucosa $\left(\chi^{2}=19.728, \mathrm{P}=0.000\right)$. As shown in Table III, increased E-cadherin expression in gastric cancer tissues strongly correlated with a better differentiation status $(\mathrm{P}=0.000)$ and less invasion $(\mathrm{P}=0.004)$. By Lauren classification, higher expression level of E-cadherin was found in tumors of intestinal type than in tumors of diffuse type $(\mathrm{P}=0.002)$. The expression of E-cadherin did not appear to be associated with age, gender, tumor size and lymph node metastasis. 

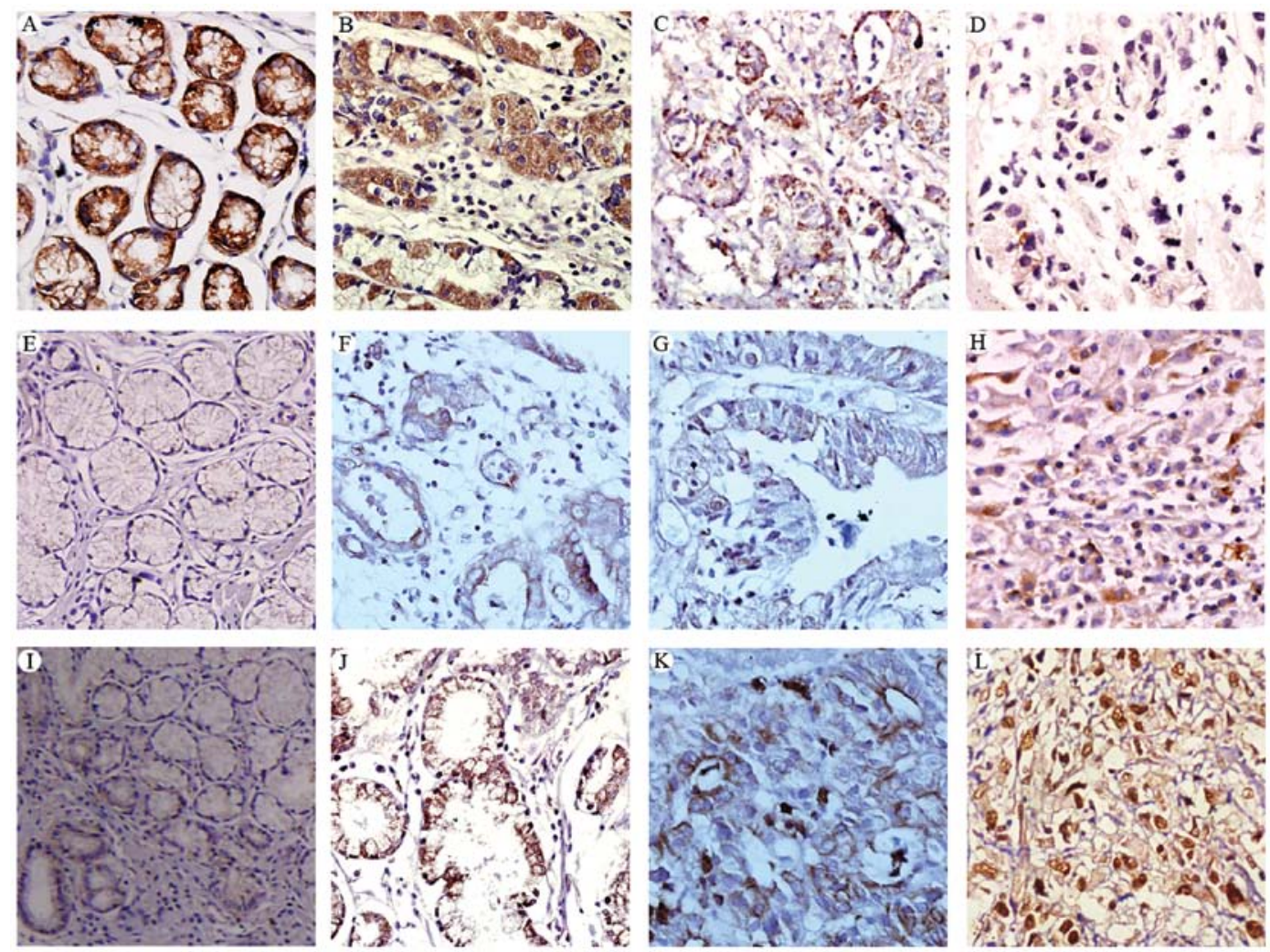

Figure 1. Immunohistochemical staining of E-cadherin (A-D), NF-kB (E-H), and Snail (I-L) in normal gastric mucosa (A, E, I) and gastric cancer tissues (B-D, $\mathrm{F}, \mathrm{G}, \mathrm{H}, \mathrm{J}, \mathrm{K}$ and L). The expression levels of these proteins were examined in well-differentiated (B, E-cadherin; F, NF- $\mathrm{KB}$; J, Snail), moderately differentiated (C, E-cadherin; G, NF-кB; K, Snail), and poorly differentiated (D, E-cadherin; H, NF-кB; L, Snail) gastric cancer tissues. Representative images are shown. Original magnification, $\mathrm{x} 200$.

Table III. Relationship between E-cadherin expression and clinicopathological factors in 189 patients with gastric cancer.

\begin{tabular}{|c|c|c|c|c|c|c|}
\hline \multirow[b]{2}{*}{ Variables } & \multicolumn{2}{|c|}{ E-cadherin } & \multirow[b]{2}{*}{ Total } & \multirow[b]{2}{*}{ Positive rate $(\%)$} & \multirow[b]{2}{*}{$\chi^{2}$} & \multirow[b]{2}{*}{ P-value } \\
\hline & Positive & Negative & & & & \\
\hline Gender & & & & & 0.416 & 0.519 \\
\hline Female & 8 & 36 & 44 & 18.2 & & \\
\hline Male & 33 & 112 & 145 & 22.8 & & \\
\hline Age (years) & & & & & 0.673 & 0.412 \\
\hline$<50$ & 9 & 42 & 51 & 17.6 & & \\
\hline$\geq 50$ & 32 & 106 & 138 & 23.2 & & \\
\hline Tumor size (cm) & & & & & 2.382 & 0.123 \\
\hline$<5$ & 19 & 51 & 70 & 27.1 & & \\
\hline$\geq 5$ & 21 & 98 & 119 & 17.6 & & \\
\hline Lymph node metastasis & & & & & 2.948 & 0.086 \\
\hline No & 21 & 52 & 73 & 28.8 & & \\
\hline Yes & 21 & 95 & 116 & 18.1 & & \\
\hline Differentiation status & & & & & 14.294 & 0.000 \\
\hline Well/moderate & 30 & 59 & 89 & 33.7 & & \\
\hline Poor & 11 & 89 & 100 & 11.0 & & \\
\hline Depth of tumor invasion & & & & & 8.338 & 0.004 \\
\hline Without serosal invasion & 17 & 29 & 46 & 37.0 & & \\
\hline Serosal invasion & 24 & 119 & 143 & 16.8 & & \\
\hline Lauren classification & & & & & 9.702 & 0.002 \\
\hline Intestinal type & 30 & 67 & 97 & 30.9 & & \\
\hline Diffuse type & 10 & 75 & 85 & 11.8 & & \\
\hline
\end{tabular}


Table IV. Relationship between NF- $\mathrm{B}$ expression and clinicopathological factors in 189 patients with gastric cancer.

\begin{tabular}{|c|c|c|c|c|c|c|}
\hline \multirow[b]{2}{*}{ Variables } & \multicolumn{2}{|c|}{ NF- $\kappa B$} & \multirow[b]{2}{*}{ Total } & \multirow[b]{2}{*}{ Positive rate $(\%)$} & \multirow[b]{2}{*}{$\chi^{2}$} & \multirow[b]{2}{*}{ P-value } \\
\hline & Positive & Negative & & & & \\
\hline Gender & & & & & 1.483 & 0.223 \\
\hline Female & 30 & 14 & 44 & 68.2 & & \\
\hline Male & 112 & 33 & 145 & 77.2 & & \\
\hline Age (years) & & & & & 1.034 & 0.309 \\
\hline$<50$ & 41 & 10 & 51 & 80.4 & & \\
\hline$\geq 50$ & 101 & 37 & 138 & 73.2 & & \\
\hline Tumor size $(\mathrm{cm})$ & & & & & 1.567 & 0.211 \\
\hline$<5$ & 49 & 21 & 70 & 70.0 & & \\
\hline$\geq 5$ & 93 & 26 & 119 & 78.2 & & \\
\hline Lymph node metastasis & & & & & 5.600 & 0.018 \\
\hline No & 48 & 25 & 73 & 65.6 & & \\
\hline Yes & 94 & 22 & 116 & 81.0 & & \\
\hline Differentiation status & & & & & 5.361 & 0.021 \\
\hline Well/moderate & 60 & 29 & 89 & 67.4 & & \\
\hline Poorly & 82 & 18 & 100 & 82.0 & & \\
\hline Depth of tumor invasion & & & & & 6.619 & 0.010 \\
\hline Without serosal invasion & 28 & 18 & 46 & 60.9 & & \\
\hline Serosal invasion & 114 & 29 & 143 & 79.7 & & \\
\hline Lauren classification & & & & & 7.284 & 0.007 \\
\hline Intestinal type & 64 & 33 & 97 & 66.0 & & \\
\hline Diffuse type & 71 & 14 & 85 & 83.5 & & \\
\hline
\end{tabular}

Expression pattern of $N F-\kappa B$. NF- $\kappa \mathrm{B}$ was detected in the cytoplasmic and nuclear portions of cells in normal gastric mucosa, matched non-cancerous gastric tissues and gastric cancer tissues to a various extent. Unlike E-cadherin, gastric cancer tissues (Fig. 1F-H) expressed a significantly higher level of NF- $\kappa \mathrm{B}$ than non-cancerous gastric tissues (data not shown) and normal gastric mucosa (Fig. 1E). Among the gastric cancer tissues, a higher level of $\mathrm{NF}-\kappa \mathrm{B}$ was detected in poorly differentiated cancer tissues (Fig. 1H) than in well/moderately differentiated cancer tissues (Fig. $1 \mathrm{G}$ and F). Overall, NF- $\mathrm{BB}$ was detected in $75.1 \%(142 / 189)$ of gastric cancer tissues, $42.6 \%(23 / 54)$ of matched non-cancerous gastric tissues, and $15.6 \%(5 / 32)$ of normal gastric mucosal tissues. By $\chi^{2}$ test, the expression of $\mathrm{NF}-\kappa \mathrm{B}$ was significantly higher in gastric cancer tissues compared to that in the matched non-cancerous gastric tissues $\left(\chi^{2}=20.404, P=0.000\right)$ and normal gastric mucosa $\left(\chi^{2}=43.511, \mathrm{P}=0.000\right)$. Matched non-cancerous gastric tissues also expressed a higher level of NF- $\kappa \mathrm{B}$ than the normal gastric mucosa $\left(\chi^{2}=6.655, \mathrm{P}=0.010\right)$. In patients with gastric cancers, increased expression of $\mathrm{NF}-\kappa \mathrm{B}$ was found to be strongly correlated with an increased tendency for lymph node metastasis $(\mathrm{P}=0.018)$, deeper tumor invasion $(\mathrm{P}=0.010)$, poor tumor differentiation $(\mathrm{P}=0.021)$, and diffuse type of cancer histology $(\mathrm{P}=0.007)$ (Table IV). The expression of $\mathrm{NF}-\kappa \mathrm{B}$ was, however, not associated with gender, age and tumor size.

Expression pattern of Snail. Snail had a similar expression pattern as $\mathrm{NF}-\kappa \mathrm{B}$ in that it was detected in the cytoplasmic and nuclear compartments of cells in normal gastric mucosa, matched non-cancerous gastric tissues, and gastric cancer tissues. Gastric cancer tissues (Fig. 1J-L) expressed a significantly higher level of Snail than non-cancerous gastric tissues (data not shown) and normal gastric mucosa (Fig. 1I). Among the gastric cancer tissues, a higher level of Snail was detected in poorly differentiated cancer tissues (Fig. 1L) than in well/moderately differentiated cancer tissues (Fig. 1J and $\mathrm{H}$ ). Overall, Snail was detected in $75.7 \%$ (143/189) of gastric cancer tissues, $48.45 \%(26 / 54)$ of matched non-cancerous gastric tissues, and $18.75 \%(6 / 32)$ of normal gastric mucosal tissues. By $\chi^{2}$ test, the expression of Snail was significantly higher in gastric cancer tissues compared to that in the matched non-cancerous gastric tissues $\left(\chi^{2}=23.67, \mathrm{P}=0.000\right)$ and that in normal gastric mucosa $\left(\chi^{2}=55.95, \mathrm{P}=0.000\right)$. Matched noncancerous gastric tissues also expressed a higher level of Snail than that in the normal gastric mucosa $\left(\chi^{2}=7.89, \mathrm{P}=0.010\right)$.

As shown in Table $\mathrm{V}$, in patients with gastric cancer, increased expression of Snail was found to be strongly correlated with increased potential for lymph node metastasis $(\mathrm{P}=0.03)$, increased tumor invasion $(\mathrm{P}=0.018)$, poor tumor differentiation $(\mathrm{P}=0.032)$, and diffuse type of cancer histology $(\mathrm{P}=0.003)$. Similar to $\mathrm{NF}-\kappa \mathrm{B}$, the expression of Snail was not associated with gender, age and tumor size.

Effect of $N F-\kappa B$ blockade on the expression of E-cadherin and Snail. The above results showed that in gastric cancer tissues, there was a close correlation between the expression of $\mathrm{NF}-\kappa \mathrm{B}$, 
Table V. Relationship between Snail expression and clinicopathological factors in the 189 patients with gastric cancer.

\begin{tabular}{|c|c|c|c|c|c|c|}
\hline \multirow[b]{2}{*}{ Variables } & \multicolumn{2}{|c|}{ Snail } & \multirow[b]{2}{*}{ Total } & \multirow[b]{2}{*}{ Positive rate (\%) } & \multirow[b]{2}{*}{$\chi^{2}$} & \multirow[b]{2}{*}{ P-value } \\
\hline & Positive & Negative & & & & \\
\hline Gender & & & & & 0.054 & 0.816 \\
\hline Female & 32 & 12 & 44 & 72.7 & & \\
\hline Male & 111 & 34 & 145 & 76.6 & & \\
\hline Age (years) & & & & & 0.691 & 0.406 \\
\hline$<50$ & 40 & 11 & 51 & 78.4 & & \\
\hline$\geq 50$ & 103 & 35 & 138 & 74.6 & & \\
\hline Tumor size $(\mathrm{cm})$ & & & & & 3.035 & 0.081 \\
\hline$<5$ & 48 & 22 & 70 & 68.6 & & \\
\hline$\geq 5$ & 95 & 24 & 119 & 79.8 & & \\
\hline Lymph node metastasis & & & & & 4.708 & 0.03 \\
\hline No & 49 & 24 & 73 & 67.1 & & \\
\hline Yes & 94 & 22 & 116 & 81.0 & & \\
\hline Differentiation status & & & & & 4.586 & 0.032 \\
\hline Well/moderate & 61 & 28 & 89 & 68.5 & & \\
\hline Poor & 82 & 18 & 100 & 82.0 & & \\
\hline Depth of tumor invasion & & & & & 5.549 & 0.018 \\
\hline Without serosal invasion & 29 & 17 & 46 & 63.0 & & \\
\hline Serosal invasion & 114 & 29 & 143 & 79.7 & & \\
\hline Lauren classification & & & & & 8.563 & 0.003 \\
\hline Intestinal type & 67 & 30 & 97 & 69.1 & & \\
\hline Diffuse type & 70 & 15 & 85 & 82.4 & & \\
\hline
\end{tabular}
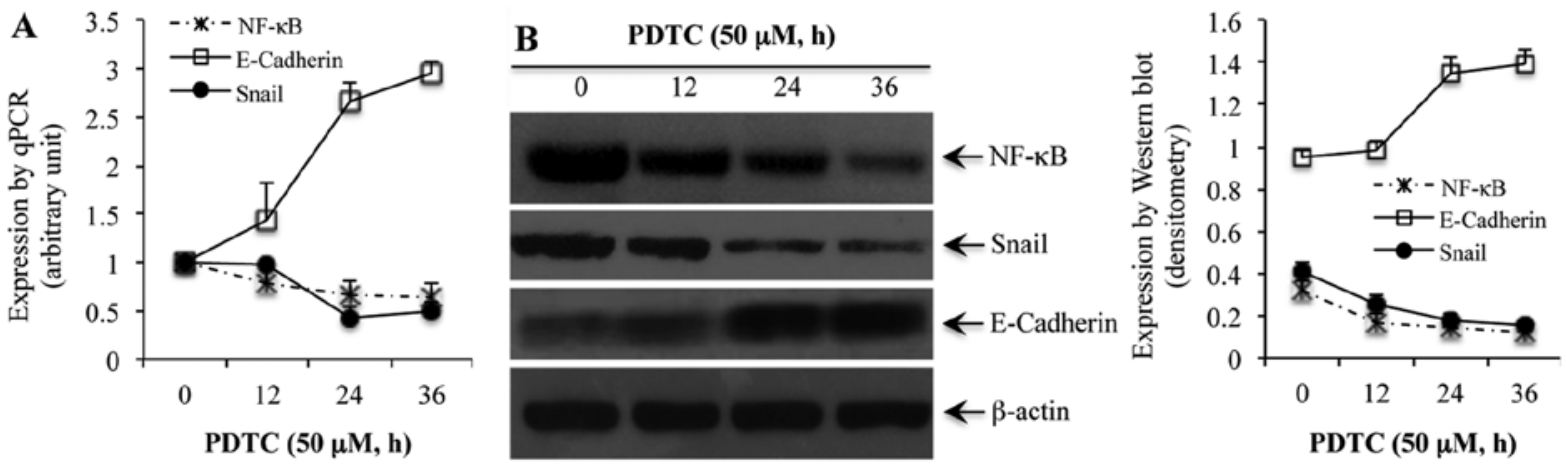

Figure 2. SGC7901 cells were treated with $50 \mu \mathrm{M}$ of the NF- $\kappa \mathrm{B}$ inhibitor PDTC for $0,12,24$ and 36 h. The expression of NF- $\kappa \mathrm{B}$, E-cadherin and Snail was detected at the mRNA level by qPCR (A), and protein level by western blot analysis (B, left panel), which was quantitated by densitometry (B, right panel). Representative data are shown.

E-cadherin and Snail. We proposed that $N F-\kappa B$ may regulate the expression of E-cadherin via the transcription factor Snail. In order to examine for this, we chose gastric cancer cell line SGC7901 as a model to investigate whether modulation of NF- $\kappa \mathrm{B}$ in this cell line could affect the expression of E-cadherin and Snail.

Following treatment of SGC7901 cells with $50 \mu \mathrm{M}$ of the $\mathrm{NF}-\kappa \mathrm{B}$ inhibitor PDTC, for 0, 12, 24 and $36 \mathrm{~h}$, a time-dependent reduction in NF- $\kappa$ B was noted at the mRNA (Fig. 2A) and protein (Fig. 2B) levels. Similarly, PDTC-induced reduction of $\mathrm{NF}-\kappa \mathrm{B}$ in SGC7901 cells was associated with a reduced expression of Snail in a time-dependent manner at both the mRNA and protein levels (Fig. 2). On the other hand, blockade of NF- $\kappa$ B with PDTC rendered a time-dependent increase in the expression of E-cadherin at both the mRNA and protein levels (Fig. 2).

\section{Discussion}

Gastric cancer is a multifactorial disease. Despite numerous studies, the molecular mechanisms for gastric cancer development have not yet been clarified. Our previous studies 
demonstrated that loss of E-cadherin contributes to the local and distant spread of gastric cancer $(15,27)$. The expression and function of E-cadherin can be regulated by many factors such as $\beta$-catenin and $\mathrm{NF}-\kappa \mathrm{B}(15,28,29)$. Our current study suggests that in gastric cancer, increased expression and activity of $\mathrm{NF}-\kappa \mathrm{B}$ may contribute to the observed loss of E-cadherin, and this biological change may be caused through NFKB-mediated alteration in the expression of Snail.

$\mathrm{NF}-\kappa \mathrm{B}$ is a critical transcription factor involved in the regulation of many signaling pathways that are important in inflammation, the immune response and cancer development $(30,31)$. The importance of $N F-\kappa B$ in the development of gastric cancer has been well-documented (32-34). In the present study, we found a reverse correlation between the expression of E-cadherin and $\mathrm{NF}-\kappa \mathrm{B}$ in normal and malignant gastric tissues. High expression level of E-cadherin in normal gastric mucosa was correlated with a low level of $\mathrm{NF}-\kappa \mathrm{B}$, whereas in malignant gastric tissues, loss of E-cadherin was correlated with an increased activity of NF- $\kappa \mathrm{B}$.

E-cadherin is a cell-cell adhesion molecule that plays an important role in the formation of cell polarity and tissue architecture $(8,9)$. Although studies on E-cadherin-deficient mice have provided little support concerning the role of E-cadherin in the development of gastric adenocarcinoma (17), numerous studies have shown that loss of E-cadherin is closely related to increased tumor cell migration, more aggressive invasion and metastasis, and poor prognosis of gastric cancer $(35,36)$. Additionally, E-cadherin expression negatively controls the transcriptional activity of NF- $\mathrm{NB}$ (29). We speculated that the inverse relationship between these two molecules may be an important mechanism in gastric cancer formation and metastasis.

The inverse correlation between E-cadherin and NF- $\kappa \mathrm{B}$ was recapitulated in our in vitro study in gastric cancer cells. When NF- $\kappa$ B was blocked using its chemical inhibitor PDTC in SGC7901 cells (as shown by a time-dependent decrease in the NF- $\kappa \mathrm{B}$ subunit p65 at the mRNA and protein levels), we observed a time-dependent increase in the expression of E-cadherin. Such an inverse correlation between NF- $\kappa \mathrm{B}$ and E-cadherin may be regulated by NF- $\kappa \mathrm{B}$-regulated Snail activity, as blockade of NF- $\kappa \mathrm{B}$ was also followed by a timedependent inhibition of Snail. As blockade of NF- $\kappa \mathrm{B}$ has been shown to inhibit the growth of cancer cells (37-40), we believe that NF- $\mathrm{NB}$-mediated cancer cell growth may be regulated through the transcription factor Snail.

Snail is an important transcription factor that has been shown to regulate many extracellular matrix genes $(20,41,42)$. Several studies have demonstrated that Snail functions as a direct inhibitor for the transcription of E-cadherin $(43,44)$, particularly in malignant tumors (45). In addition, Snail was recognized as an independent marker for the prognosis of patients with gastric carcinoma (46). Our study indicates that in gastric cancer cells, the regulatory effect of NF- $\kappa \mathrm{B}$ on its target genes such as E-cadherin is likely mediated through Snail. To support this finding, previous studies have shown the presence of the NF- $\mathrm{B}$ binding sequence on the promoter of the Snail gene $(47,48)$.

As $N F-\kappa B$ plays an important role in the control of growth and survival of cancer cells, and loss of E-cadherin is closely related to the development of gastric cancer and its metastasis, our data not only provide a new mechanism of how NF- $\kappa \mathrm{B}$ may regulate E-cadherin in gastric cancer, but also potentially opens a new avenue for possible therapeutic targeting. If Snail is a critical intermediating factor between $N F-\kappa B$ and its targets, then specific targeting of Snail may be of therapeutic benefit. Further studies using more cell lines involving specific knockdown of Snail (e.g., using siRNA) and appropriate in vivo studies are needed to generate more valuable data to confirm such an assumption.

In conclusion, our results showed that in gastric cancer, loss of E-cadherin in gastric epithelial cells may be regulated through NF- $\mathrm{B}$-mediated Snail signaling. Further studies are warranted to clarify the role of the NF- $\kappa \mathrm{B}-$ Snail-E-cadherin axis in gastric cancer.

\section{Acknowledgements}

We thank Drs Zhaofeng Chen, Lina Wang, and Meikai Zhou from the First Clinical Medical School of Lanzhou University for their assistance in TMA construction and immunohistochemistry. This study was funded by the National Natural Science Funding of China (grant ID: no. 432355/041003). Dr Z. Hu's visiting study to the Storr Liver Unit of the Westmead Millennium Institute was supported by the Robert W. Storr Bequest. Dr L. Qiao was supported by the Robert W. Storr Bequest and the Career Development and Support Fellowship Future Research Leader Grant of the NSW Cancer Institute, NSW, Australia.

\section{References}

1. Jemal A, Bray F, Center MM, Ferlay J, Ward E and Forman D: Global cancer statistics. CA Cancer J Clin 61: 69-90, 2011.

2. Siegel R, Ward E, Brawley O and Jemal A: Cancer statistics, 2011: the impact of eliminating socioeconomic and racial disparities on premature cancer deaths. CA Cancer J Clin 61: 212-236, 2011.

3. Yang L, Parkin DM, Ferlay J, Li L and Chen Y: Estimates of cancer incidence in China for 2000 and projections for 2005. Cancer Epidemiol Biomarkers Prev 14: 243-250, 2005.

4. Yang L: Incidence and mortality of gastric cancer in China. World J Gastroenterol 12: 17-20, 2006.

5. Baeuerle PA and Baltimore D: NF- $\kappa$ B: ten years after. Cell 87: 13-20, 1996.

6. Bours V, Dejardin E, Goujon-Letawe F, Merville MP and Castronovo V: The NF-kappa B transcription factor and cancer: high expression of NF-kappa B- and I kappa B-related proteins in tumor cell lines. Biochem Pharmacol 47: 145-149, 1994.

7. Baldwin AS: Control of oncogenesis and cancer therapy resistance by the transcription factor NF- $\mathrm{B}$. J Clin Invest 107: 241-246, 2001.

8. Frixen UH, Behrens J, Sachs M, et al: E-cadherin-mediated cell-cell adhesion prevents invasiveness of human carcinoma cells. J Cell Biol 113: 173-185, 1991.

9. Hirohashi S: Inactivation of the E-cadherin-mediated cell adhesion system in human cancers. Am J Pathol 153: 333-339, 1998.

10. Gabbert HE, Mueller W, Schneiders A, et al: Prognostic value of E-cadherin expression in 413 gastric carcinomas. Int J Cancer 69: 184-189, 1996.

11. Mao Z, Ma X, Rong Y, et al: Connective tissue growth factor enhances the migration of gastric cancer through downregulation of E-cadherin via the NF-кB pathway. Cancer Sci 102: 104-110, 2011.

12. Ghadimi BM, Behrens J, Hoffmann I, Haensch W, Birchmeier W and Schlag PM: Immunohistological analysis of E-cadherin, alpha-, beta-and gamma-catenin expression in colorectal cancer: implications for cell adhesion and signaling. Eur J Cancer 35: 60-65, 1999.

13. Pignatelli M, Ansari TW, Gunter P, et al: Loss of membranous E-cadherin expression in pancreatic cancer: correlation with lymph node metastasis, high grade, and advanced stage. J Pathol 174: 243-248, 1994. 
14. Oka H, Shiozaki H, Kobayashi K, et al: Expression of E-cadherin cell adhesion molecules in human breast cancer tissues and its relationship to metastasis. Cancer Res 53: 1696-1701, 1993.

15. Zhou Y, Li G, Wu J, et al: Clinicopathological significance of E-cadherin, VEGF, and MMPs in gastric cancer. Tumour Biol 31: 549-558, 2010

16. Kyrlagkitsis I and Karamanolis DG: Genes and gastric cancer. Hepatogastroenterology 51: 320-327, 2004.

17. Mimata A, Fukamachi H, Eishi Y and Yuasa Y: Loss of E-cadherin in mouse gastric epithelial cells induces signet ring-like cells, a possible precursor lesion of diffuse gastric cancer. Cancer Sci 102: 942-950, 2011.

18. Nieto MA: The snail superfamily of zinc-finger transcription factors. Nat Rev Mol Cell Biol 3: 155-166, 2002.

19. Bonavida B and Baritaki S: Dual role of NO donors in the reversal of tumor cell resistance and EMT: downregulation of the NF- $\kappa B /$ Snail/YY1/RKIP circuitry. Nitric Oxide 24: 1-7, 2011

20. Wu Y and Zhou BP: Snail: more than EMT. Cell Adh Migr 4: 199-203, 2010

21. Rosivatz E, Becker I, Specht K, et al: Differential expression of the epithelial-mesenchymal transition regulators Snail, SIP1, and Twist in gastric cancer. Am J Pathol 161: 1881-1891, 2002.

22. Castro Alves C, Rosivatz E, Schott C, et al: Slug is overexpressed in gastric carcinomas and may act synergistically with SIP1 and Snail in the down-regulation of E-cadherin. J Pathol 211: 507-515, 2007.

23. Bosman FT: WHO classification of tumours of the digestive system. In: World Health Organization. International Agency for Research on Cancer. 4th edition. IARC Press, Lyon, 2010.

24. Volm M, Koomagi R and Mattern J: Prognostic value of vascular endothelial growth factor and its receptor Flt-1 in squamous cell lung cancer. Int J Cancer 74: 64-68, 1997.

25. Vichai V and Kirtikara K: Sulforhodamine B colorimetric assay for cytotoxicity screening. Nat Protoc 1: 1112-1116, 2006.

26. Woolston C and Martin S: Analysis of tumor and endothelial cell viability and survival using sulforhodamine B and clonogenic assays. Methods Mol Biol 740: 45-56, 2011.

27. Zhou Y, Ran J, Tang C, et al: Effect of celecoxib on E-cadherin, VEGF, microvessel density and apoptosis in gastric cancer. Cancer Biol Ther 6: 269-275, 2007.

28. Dentice M, Luongo C, Ambrosio R, et al: Beta-catenin regulates deiodinase levels and thyroid hormone signaling in colon cancer cells. Gastroenterology 143: 1037-1047, 2012.

29. Solanas G, Porta-de-la-Riva M, Agustí C, et al: E-cadherin controls beta-catenin and NF-kappaB transcriptional activity in mesenchymal gene expression. J Cell Sci 121: 2224-2234, 2008.

30. Sebastian K, Reza F, Christoph C, et al: Time dependency and topography of hepatic NF- $\kappa \mathrm{B}$ activation after hemorrhagic shock and resuscitation in mice. Shock 38: 486-492, 2012.

31. Bernardi FC, Felisberto F, Vuolo F, et al: Oxidative damage inflammation, and toll-like receptor 4 pathway are increased in preeclamptic patients: a case-control study. Oxid Med Cell Longev 2012: 636419, 2012.

32. Jiang $\mathrm{Z}, \mathrm{Wu} \mathrm{W}$ and Qian ML: Cellular damage and apoptosis along with changes in NF-kappa B expression were induced with contrast agent enhanced ultrasound in gastric cancer cells and hepatoma cells. Cancer Cell Int 12: 8, 2012.
33. Lee KH and Kim JR: Regulation of HGF-mediated cell proliferation and invasion through NF- $\kappa \mathrm{B}$, JunB, and MMP-9 cascades in stomach cancer cells. Clin Exp Metastasis 29: 263-272, 2012.

34. Li J, Shen L, Lu FR, et al: Plumbagin inhibits cell growth and potentiates apoptosis in human gastric cancer cells in vitro through the NF- $\mathrm{KB}$ signaling pathway. Acta Pharmacol Sin 33 242-249, 2012.

35. Uchikado Y, Okumura H, Ishigami S, et al: Increased Slug and decreased E-cadherin expression is related to poor prognosis in patients with gastric cancer. Gastric Cancer 14: 41-49, 2011.

36. Maehata Y, Hirahashi M, Aishima S, et al: Significance of dysadherin and E-cadherin expression in differentiated-type gastric carcinoma with submucosal invasion. Hum Pathol 42: 558-567, 2011.

37. Biswas DK, Shi Q, Baily S, et al: NF-kappa B activation in human breast cancer specimens and its role in cell proliferation and apoptosis. Proc Natl Acad Sci USA 101: 10137-10142, 2004.

38. Dolcet X, Llobet D, Pallares J and Matias-Guiu X: NF- $\kappa B$ in development and progression of human cancer. Virchows Arch 446: 475-482, 2005

39. Han SS, Yun H, Son DJ, et al: NF-kappaB/STAT3/PI3K signaling crosstalk in iMyc E mu B lymphoma. Mol Cancer 9: 97, 2010.

40. Fang Y, Sun H, Zhai J, et al: Antitumor activity of NF- $\kappa$ B decoy oligodeoxynucleotides in a prostate cancer cell line. Asian Pac J Cancer Prev 12: 2721-2726, 2011.

41. Dhasarathy A, Kajita M and Wade PA: The transcription factor snail mediates epithelial to mesenchymal transitions by repression of estrogen receptor-alpha. Mol Endocrinol 21: 2907-2918, 2007.

42. Harder JL, Whiteman EL, Pieczynski JN, Liu CJ and Margolis B: Snail destabilizes cell surface Crumbs3a. Traffic 13: 1170-1185, 2012.

43. Becker KF, Rosivatz E, Blechschmidt K, Kremmer E, Sarbia M and Höfler H: Analysis of the E-cadherin repressor Snail in primary human cancers. Cells Tissues Organs 185: 204-212, 2007.

44. Blechschmidt K, Kremmer E, Hollweck R, et al: The E-cadherin repressor snail plays a role in tumor progression of endometrioid adenocarcinomas. Diagn Mol Pathol 16: 222-228, 2007.

45. Spaderna S, Schmalhofer O, Wahlbuhl M, et al: The transcriptional repressor ZEB1 promotes metastasis and loss of cell polarity in cancer. Cancer Res 68: 537-544, 2008.

46. He H, Chen W, Wang X, et al: Snail is an independent prognostic predictor for progression and patient survival of gastric cancer. Cancer Sci 103: 1296-1303, doi: 10.1111/j.13497006.2012.02295.x.

47. Bachelder RE, Yoon SO, Franci C, de Herreros AG and Mercurio AM: Glycogen synthase kinase-3 is an endogenous inhibitor of Snail transcription: implications for the epithelialmesenchymal transition. J Cell Biol 168: 29-33, 2005.

48. Julien S, Puig I, Caretti E, et al: Activation of NF-kappaB by Akt upregulates Snail expression and induces epithelium mesenchyme transition. Oncogene 26: 7445-7456, 2007. 